\title{
The SL autoantibody-antigen system: clinical and biochemical studies
}

\author{
ROBERT M BERNSTEIN, ${ }^{1}$ STEPHEN H MORGAN,${ }^{1}$ CHRISTOPHER C BUNN, \\ RICHARD C GAINEY, ${ }^{1}$ GRAHAM R VHUGHES, ${ }^{1}$ AND \\ MICHAEL B MATHEWS ${ }^{2}$
}

From the ${ }^{1}$ Rheumatology Unit, Department of Medicine, Royal Postgraduate Medical School, Hammersmith Hospital, London W12 OHS; and the ${ }^{2}$ Cold Spring Harbor Laboratory, Cold Spring Harbor, NY 11724, $U S A$

SUMmARY A recently described autoantibody, SL, was found in serum from 27 patients with autoimmune disease, including 20 with systemic lupus erythematosus (SLE) where the frequency was $7 \%$. Analysis of clinical, serological, and HLA data from 119 SLE patients showed no positive associations with anti-SL antibody apart from a higher frequency of non-infective fever. Most SL positive sera contained other precipitins, notably antibodies to Ro(SS-A) and the proliferating cell nuclear antigen, PCNA. Anti-SL IgG recognised a protein of 32000 daltons without associated RNA. This polypeptide was distinguished from a similarly sized component of the Sm and RNP ribonucleoprotein particles by demonstrating different products of partial proteolysis. Although anti-SL antibody is of limited clinical importance, it occurs with twice the frequency of anti-Sm antibody in white patients with SLE. Preliminary studies indicate that SL and the Japanese $\mathrm{Ki}$ system are identical.

Key words: antinuclear antibody, autoimmunity, connective tissue disease, systemic lupus erythematosus, Sjögren's syndrome, thyroid disease, 32 kilodalton cellular protein, Sm, RNP, $\mathrm{Ki}$.

Antibodies directed against saline soluble cellular antigens are found in the sera of patients with many forms of systemic autoimmune disease. ${ }^{1}$ Although some are of diagnostic and prognostic value, most antibodies are not totally disease specific. ${ }^{2}$ For example, antibody to the anti-Ro(SS-A) antigen occurs in a number of connective tissue disorders, though most frequently in primary sicca syndrome and systemic lupus erythematosus (SLE). Harmon et al have described their preliminary clinical experience with a subset of patients identified by a new precipitating antigen/antibody system designated SL (sicca lupus). ${ }^{3}$

In a survey of over 1000 patients with autoimmune disease, including 300 with SLE, we noted a precipitin line that was named PL-2 in our labora-

\footnotetext{
Accepted for publication 25 September 1985.

Correspondence to Dr Robert M Bernstein, Rheumatism Research Centre, The Royal Infirmary, University of Manchester, Oxford Road, Manchester M13 9WL.

Presented in part at the 1st meeting of the British Society for Rheumatology in Bristol, 1984 and at the 48th meeting of the American Rheumatism Association, Minneapolis-St Paul, 1984.
}

tory. Through exchange of serum samples PL-2 and SL were shown to be identical. ${ }^{1}$ This report concerns a clinical study of patients with anti-SL antibody and a preliminary biochemical characterisation of the SL antigen.

\section{Patients and methods}

Clinical and serological data on 20 patients with anti-SL antibody were reviewed. Serological data and the referring physician's diagnosis were available in a further seven cases seen elsewhere. The findings in the anti-SL positive patients who had $\mathrm{SLE}^{4}$ were compared with data collected at the same time by chart review of 107 SLE patients who were anti-SL negative. Clinical and laboratory features were defined according to the 1982 revised criteria for the classification of $\mathrm{SLE}^{4}$ or according to accepted clinical practice (e.g., splenomegaly means a palpable spleen). Despite varying lengths of follow up, clinical features noted at any time were recorded as positive whether or not they recurred or persisted. 
Statistical significance was assessed by the $\chi^{2}$ test. Because so many tests were carried out two approaches were taken to avoid attributing undue significance to high $\dot{\chi}^{2}$ results arising by chance. ${ }^{5}$ Firstly, in the usual approach $p$ values were multiplied by 36 (as 36 tests were carried out). Secondly, and less conservatively, square roots of $\chi^{2}$ results were ordered and plotted against half-normal scores to establish visually whether high results had deviated from the normal distribution (Fig. 1). ${ }^{6}$

Antibodies to soluble cellular antigens were detected by counterimmunoelectrophoresis (CIE) using extracts of rabbit thymus and human spleen,
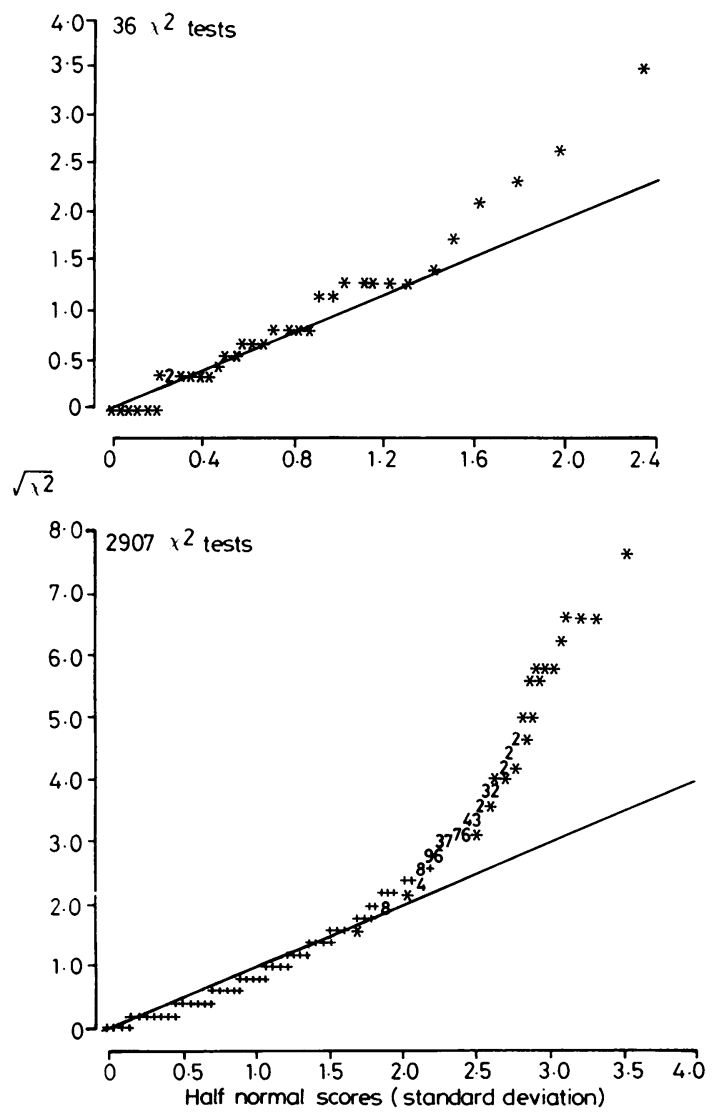

Fig. 1 Statistical analysis. Half-normal plots of the square roots of $\chi^{2}$ values obtained in the present study (upper panel) and in a more extensive intercomparison of 88 variables in the same group of SLE patients (lower panel). ${ }^{7} \sqrt{\chi}$ follows the normal distribution (straight line with slope of $1 \cdot 0)$ until higher values emerge. The diverging points indicate $\chi^{2}$ lest results that are less likely to have arisen by chance through multiple testing. Symbols used: *=one datum point; 2-9=two to nine points in proximity; $+=10$ or more datum points in proximity. and precipitin systems were identified by comparison with reference sera in adjacent wells. ${ }^{18}$ Antinuclear antibodies were detected by indirect im- $\overrightarrow{\vec{\Omega}}$ munofluorescence on rat liver frozen sections and insome cases on the $\mathrm{HEp}_{2}$ cell substrate as well. ${ }^{9} \mathrm{C}$ Rheumatoid factor was measured by the slide latex $\overline{\bar{c}}$. test (Ortho Diagnostics, High Wycombe, UK). HLA-A, B, and DR typing of 87 SLE patients, including six with anti-SL antibody, was performed ${ }^{\text {कs }}$ with a standard microcytotoxicity assay. ${ }^{10}$

For immunoprecipitations mediated by Staphylococcus aureus protein $\mathrm{A}$, IgG preparations and HeLa cell extracts labelled with $\left[{ }^{35} \mathrm{~S}\right]$ methionine, $\left[{ }^{32} \mathrm{P}\right]$ phosphate, or $\left[{ }^{3} \mathrm{H}\right]$ leucine were employed as described in detail elsewhere. ${ }^{11} 12$ Immunoprecipi-cr tates were analysed by gel electrophoresis ${ }^{13}$ andir autoradiography or photofluorography. Immunoblotting with HeLa cell extracts was carried out according to Towbin et al. ${ }^{14}$

For partial proteolysis immunoprecipitated pro- $\vec{z}$ tein was eluted from the dried gel after photo fluorography by boiling in a solution containing $\overrightarrow{ }$ $0.5 \%$ sodium dodecyl sulphate (SDS), $10 \mathrm{mM}$ 2-mercaptoethanol, and $10 \mathrm{mM}$ trometamol hydrochloride (TRIS-HCl) pH 7.4. Aliquots of theo proteins to be compared, containing approximately equal radioactivity, were incubated with varyingo quantities $(0-100 \mathrm{ng})$ of protease from $S$ aureuso strain V8. ${ }^{15}$ After digestion for $15 \mathrm{~min}$ at $37^{\circ} \mathrm{C}$ the@ products were resolved by electrophoresis in $20 \% \overrightarrow{\vec{B}}$ SDS-polyacrylamide gels. ${ }^{13}$

\section{Results}

CLINICAL AND SEROLOGICAL CORRELATION Over a three year period anti-SL antibody was identified in the serum of 27 patients. Twenty four were female and the age range was $13-70$ yearso (mean 31). Table 1 shows the diagnoses made and₹ the frequency of anti-SL antibody in patients witho these conditions. The highest prevalence was in SLE diagnosis

\begin{tabular}{|c|c|c|}
\hline Diagnosis & Frequency & $\%$ \\
\hline Systemic lupus erythematosus & $20 / 3(k)$ & $6 \cdot 7$ \\
\hline Mixed connective tissue discase & 1150 & $2 \cdot 0$ \\
\hline Rheumatoid arthritis & $2 \div / 70$ & $2 \cdot 9$ \\
\hline Primary sicca syndrome & $2 / 60$ & $3 \cdot 3$ \\
\hline Primary biliary cirrhosis & $1 / 135$ & $0 \cdot 7$ \\
\hline Idiopathic thrombocytopenic purpura & $1 \ddagger / 110$ & 0.9 \\
\hline
\end{tabular}

This patient had arthritis. malaise. severe Raynaud's phenom enon, and anti-RNP antibody with normal DNA binding. ${ }^{15}$ tIncludes one out of eight patients with rheumatoid vasculitis (skip ulceration or neuropathy, or both).

$\ddagger$ This patient also had thyrotoxicosis. 
Table 2 Clinical, haematological, and serological features

\begin{tabular}{|c|c|c|c|c|}
\hline & \multirow{2}{*}{$\begin{array}{l}\text { Overall anti-SL } \\
\text { positive } \\
(\%)\end{array}$} & \multicolumn{3}{|l|}{ SLE patients } \\
\hline & & $\begin{array}{l}\text { Anti-SL } \\
\text { positive } \\
(\%)\end{array}$ & $\begin{array}{l}\text { Anti-SL negative } \\
\text { (white patients) } \\
(\%)\end{array}$ & $x^{2}$ \\
\hline Rash & $60(12 / 20)$ & $73(11 / 15)$ & $79(84 / 106)$ & $0 \cdot 3$ \\
\hline Photosensitivity & $37(7 / 19)$ & $36(5 / 14)$ & $54(52 / 96)$ & $1 \cdot 7$ \\
\hline Alopecia & $45(9 / 20)$ & $53(8 / 15)$ & $70(73 / 105)$ & $1 \cdot 6$ \\
\hline Mouth ulcers & $28(5 / 18)$ & $23(3 / 13)$ & $29(29 / 100)$ & 0.2 \\
\hline Raynaud's phenomenon & $37(7 / 19)$ & $36(5 / 14)$ & $52(54 / 103)$ & $1 \cdot 4$ \\
\hline Digital ischaemia vasculitis & $37(7 / 19)$ & $36(5 / 14)$ & $34(36 / 107)$ & $0 \cdot()$ \\
\hline Arthritis & $65(13 / 20)$ & $73(11 / 15)$ & $64(69 / 107)$ & $0 \cdot 5$ \\
\hline Myositis & $0(0 / 20)$ & $0(0 / 15)$ & $11(12 / 105)$ & 1.9 \\
\hline Pleurisy & $40(8 / 20)$ & $47(7 / 15)$ & $51(54 / 105)$ & $0 \cdot 1$ \\
\hline Pericarditis & $25(5 / 20)$ & $33(5 / 15)$ & $29(30 / 103)$ & $0 \cdot 1$ \\
\hline Abnormal pulmonary function & $75(6 / 8)$ & $75(6 / 8)$ & 60) $(48 / 80)$ & 0.7 \\
\hline Renal (proteinuria casts) & $30(6 / 20)$ & $40(6 / 15)$ & $52(56 / 107)$ & $0 \cdot 8$ \\
\hline Hypertension $(\geqslant 140 / 90)$ & $10(2 / 20)$ & $13(2 / 15)$ & $42(45 / 106)$ & $4 \cdot 7$ \\
\hline Fever (non-infective) & $75(15 / 20)$ & $87(13 / 15)$ & $37(40 / 107)$ & $13 \cdot 0$ \\
\hline Sicca syndrome & $35(7 / 20)$ & $27(4 / 15)$ & $31(27 / 86)$ & $0 \cdot 1$ \\
\hline Psychosis & $0(0 / 20)$ & $0(0 / 15)$ & $24(24 / 101)$ & 0.5 \\
\hline Seizures & $5(1 / 20)$ & $7(1 / 15)$ & $15(16 / 105)$ & $0 \cdot 8$ \\
\hline Thrombosis (venous or arterial) & $25(5 / 20)$ & $27(4 / 15)$ & $24(24 / 101)$ & $0 \cdot 1$ \\
\hline Stroke & $10(2 / 20)$ & $13(2 / 15)$ & $13(14 / 105)$ & $0 \cdot()$ \\
\hline Abortion & $5(1 / 19)$ & $7(1 / 15)$ & $21(15 / 72)$ & $1 \cdot 7$ \\
\hline Splenomegaly & $15(3 / 20)$ & $20(3 / 15)$ & $14(15 / 104)$ & $0 \cdot 3$ \\
\hline Lymphadenopathy & $25(5 / 20)$ & $27(4 / 15)$ & $24(25 / 104)$ & $0 \cdot 1$ \\
\hline Raised IgG (>15 g/l) & $24(4 / 17)$ & $21(3 / 14)$ & $60)(58 / 97)$ & 7.3 \\
\hline Low $\mathrm{C} 3(<60 \%$ normal pool $)$ & $39(7 / 18)$ & $47(7 / 15)$ & $49(49 / 100)$ & $0 \cdot()$ \\
\hline Anaemia $(<10 \mathrm{~g} / \mathrm{dl})$ & $50(10 / 20)$ & $60(9 / 15)$ & $59(63 / 107)$ & $0 \cdot 0$ \\
\hline Leucopenia $\left(<4 \times 10^{9} / 1\right)$ & $35(7 / 20)$ & $47(7 / 15)$ & $48(50 / 105)$ & $0 \cdot 0$ \\
\hline Thrombocytopenia $\left(<100 \times 10^{y} / 1\right)$ & $40(8 / 20)$ & $47(7 / 15)$ & $36(38 / 107)$ & 0.7 \\
\hline Steroid therapy & $65(13 / 20)$ & $80(12 / 15)$ & $93(100 / 107)$ & $3 \cdot 2$ \\
\hline Cytotoxic therapy & $40(8 / 20)$ & $40(6 / 15)$ & 6) $(64 / 106)$ & $2 \cdot 2$ \\
\hline Antimalarial therapy & $55(11 / 20)$ & 6) $(9 / 15)$ & $64(68 / 106)$ & $(0 \cdot 1$ \\
\hline Antinuclear antibodies & $100(27 / 27)$ & $100(20 / 20)$ & $91(91 / 100)$ & 1.9 \\
\hline Rheumatoid factor & $37(7 / 19)$ & $25(3 / 12)$ & $23(24 / 106)$ & $(0 \cdot 0)$ \\
\hline Anti-Ro(SS-A) & $48(13 / 27)$ & $45(9 / 20)$ & $31(33 / 106)$ & $1 \cdot 5$ \\
\hline Anti-RNP & $11(3 / 27)$ & $15(3 / 20)$ & $22(23 / 106)$ & 0.5 \\
\hline Anti-Sm & $0(0 / 27)$ & $0(0 / 20)$ & $4(4 / 106)$ & $0 \cdot 1$ \\
\hline Anti-PCNA & $11(3 / 27)$ & $15(3 / 20)$ & $3(3 / 106)$ & $5 \cdot 5$ \\
\hline
\end{tabular}

Possible associations with anti-SL antibody in SLE: fever- $p=0 .(0)(0) 3$. $p$ corrected $\left(p_{c}\right)=0.011$, relative risk 10.9: absence of hypertension- $p=0 \cdot 03, p_{c}=1 \cdot 1$; absence of raised IgG-p=0.007, $p_{c}=0 \cdot 25$; anti-PCNA antibody-p=0.(12, $p_{c}=0 \cdot 7$.

$(6.7 \%)$. In the other conditions the frequencies are rough estimates at best. Table 2 summarises the clinical and haematological data available in 20 cases (15 with SLE and one each with mixed connective tissue disease, primary sicca syndrome, rheumatoid synovitis, rheumatoid vasculitis, and idiopathic thrombocytopenic purpura with thyrotoxicosis), together with serological data on all cases. No clinical feature was particularly associated with anti-SL antibody in the SLE patients except for the more frequent record of fever (above $38^{\circ} \mathrm{C}, 100.4^{\circ} \mathrm{F}$ ) in the absence of overt infection. Sicca syndrome, assessed by Schirmer's test or lip biopsy, was not increased in patients with SL antibody; hypertension and hypergammaglobulinaemia were less common.
Two of six SL positive SLE patients carried HLADR3, not dissimilar to the $48 \%$ frequency in a further 81 white SLE patients who were anti-SL negative.

Most $(80 \%)$ of the anti-SL positive sera contained other precipitating antibodies, notably those to Ro and PCNA. Antinuclear antibody was detected by indirect immunofluorescence in every case. Where the pattern was recorded it was speckled in 14 and homogeneous in five, emphasising the polyspecificity of the sera tested; cytoplasmic and nucleolar staining was uncommon.

S L A N TIGEN

In all 16 cases tested by protein $A$ facilitated 


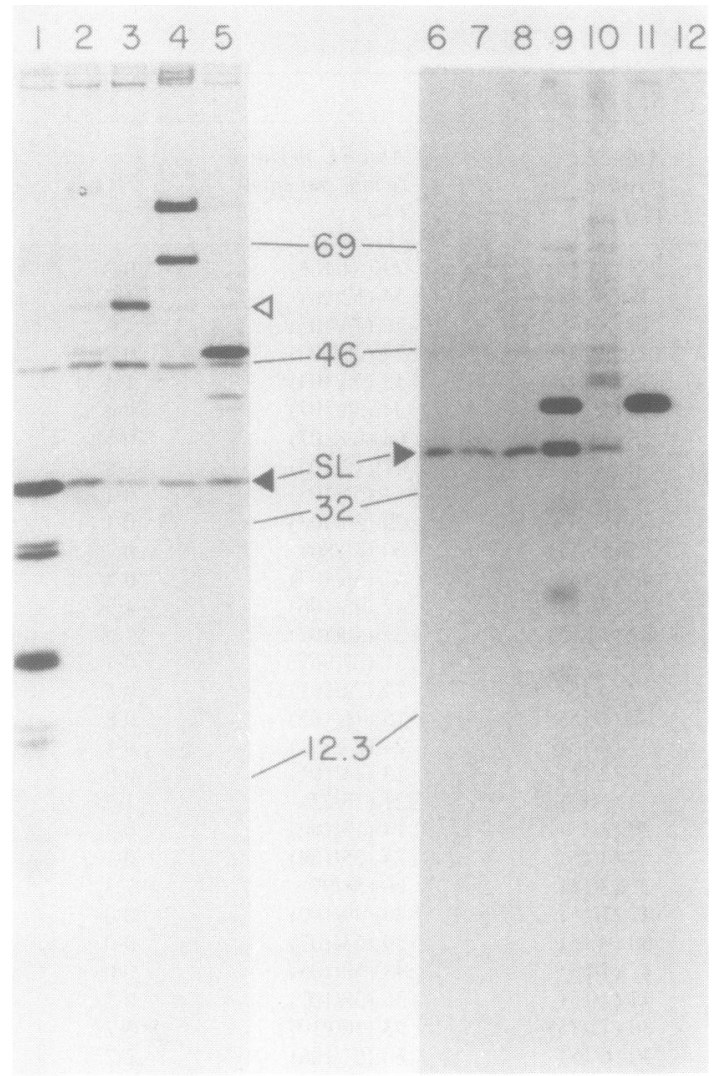

Fig. 2 Immunoprecipitation of SL antigen. ${ }^{35} S$ Labelled proteins precipitated by autoantibodies were resolved by $15 \%$ SDS-polyacrylamide gel electrophoresis and photofluorography: (I) RNP; (2) Ro, La, SL; (3) Ro, SL; (4) PL-9 (Ku), Ro, SL; (5) Ro, La (with breakdown product), $S L$; (6-8) $S L$; (9) PCNA, SL, RNP; (10) $S L$, other; (11) PCNA; (12) control. The positions of molecular weight markers (kilodaltons) are indicated; the carbonic anhydrase marker (32 kilodaltons) falls below the calibration curve from which the molecular weight of the $S L$ polypeptide was measured. An open arrowhead indicates the Ro antigen. (Actin is precipitated non-specifically, near the 46 kilodalton marker.)

immunoprecipitation anti-SL IgG recognised a $\left[{ }^{35} \mathrm{~S}\right]-$ methionine labelled polypeptide of 32000 daltons (Fig. 2), that was also detected by Western immunoblotting. There was no RNA associated with this protein, and the antigen was not phosphate labelled (data not shown). As expected from the serological studies several IgG samples also precipitated the 55000 dalton Ro antigen, 1646000 dalton La, ${ }^{111}$ or 35000 dalton PCNA. 117

As seen in Fig. 1 the SL protein has a mobility similar to that of a component of the Sm and RNP antigens. ${ }^{1}$ To discover whether or not these

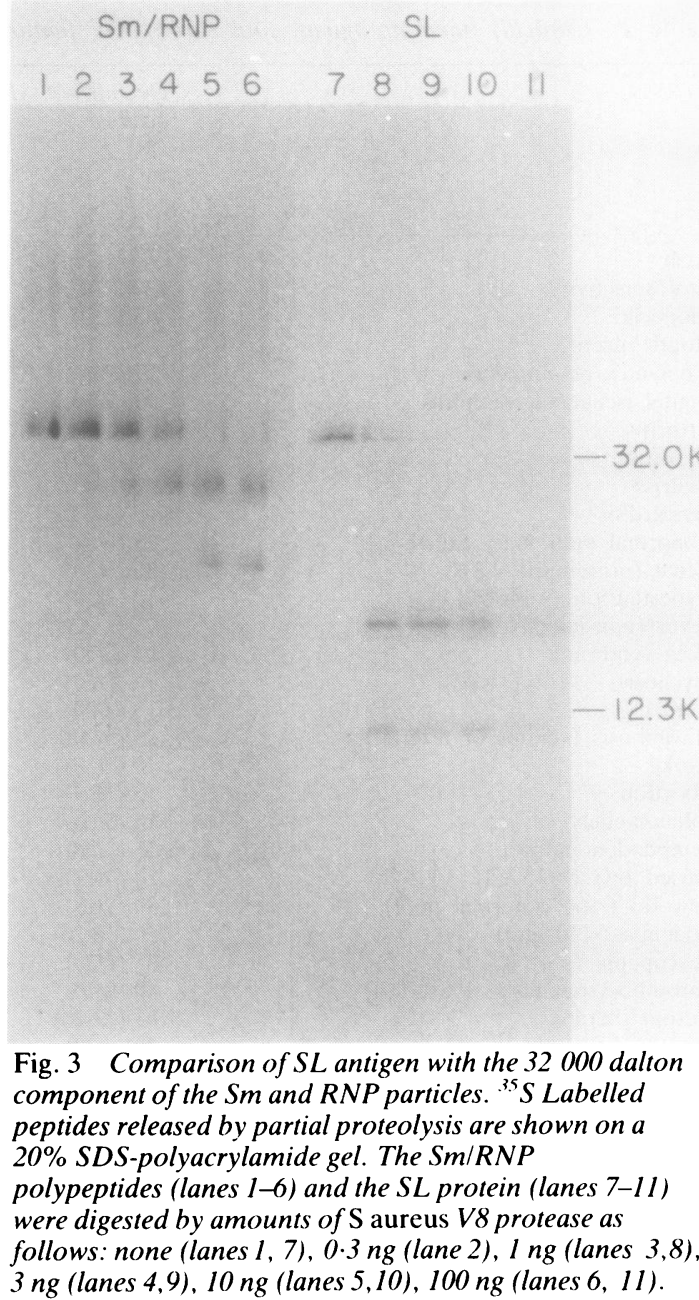

$3 \mathrm{ng}$ (lanes 4,9), $10 \mathrm{ng}$ (lanes 5,10), $100 \mathrm{ng}$ (lanes 6, 11).

polypeptides were identical they were eluted from the gel and subjected to partial proteolysis. As을. shown in Fig. 3 the peptides released from the $S L_{N}$ antigen are clearly different from those derived from $\mathrm{N}$ the Sm/RNP component, and we conclude that theN two proteins are distinct.

\section{Discussion}

Our studies show anti-SL to be a fairly uncommon autoantibody directed at a protein of 32000 daltons $\stackrel{\rho}{?}$ that does not appear to be associated with RNA. 0 The antibody was found chiefly in SLE, with a frequency of about $7 \%$, and less often in primary $\stackrel{\mathbb{Q}}{\Phi}$ sicca syndrome, mixed connective tissue disease, ${ }^{18} \stackrel{\mathbb{Q}}{\mathbb{Q}}$ primary biliary cirrhosis, rheumatoid arthritis, and rheumatoid vasculitis, as well as in a case of 
idiopathic thrombocytopenic purpura with thyrotoxicosis.

This experience parallels that of Harmon and her colleagues, who identified anti-SL antibody in a similar spectrum of disease, including SLE, sicca syndrome, autoimmune thyroid disease, and a case of rheumatoid lung disease. ${ }^{3}$ On the other hand, we could not confirm a trend to increasing cutaneous, pulmonary, or haematological abnormalities, and, despite the name 'sicca lupus' (SL), features of the sicca syndrome were found in only $35 \%$ of cases.

Most anti-SL sera contained other precipitins, particularly antibodies to Ro and PCNA. The well known associations of anti-La with anti-Ro and of anti-Sm with anti-RNP are mirrored by relations between the antigens, ${ }^{1}$ but as yet there is no sign of a connection between SL, PCNA, and Ro. We did note a similarity in size between SL and a component of the Sm and RNP complexes, and showed by peptide comparison that these proteins differ; this excludes the possibility that the SL antigen is a free component or precursor of a (U)RNP particle.

The results of immunoblotting and immunoprecipitation are complementary. The blotting study shows that anti-SL binds directly to the 32000 dalton protein, while the immunoprecipitations show that this protein is not part of a ribonucleoprotein or protein-protein complex (at least, not one that is soluble and stable). Further immunoprecipitations with cell extracts labelled with $\left[{ }^{32} \mathrm{P}\right]-$ phosphate and $\left[{ }^{3} \mathrm{H}\right]$ leucine confirmed that no other proteins are immunoprecipitated. This is an important control because some proteins such as the $68 \mathrm{~K}$ RNP antigenic polypeptide detected by immunoblotting are not labelled with methionine. ${ }^{1}$

Anti-Sm antibody was an infrequent finding in our patients with SLE. At one time there was a practice of equating all ribonuclease resistant precipitin lines with $\mathrm{Sm}$, but now several distinct precipitin systems involving protein antigens can be distinguished; ${ }^{1}$ we identify these antibodies by comparison with reference sera. Another factor influencing the frequency of anti-Sm may be the different racial mix in British and North American clinics. ${ }^{19}$ We have observed that anti-Sm antibody is up to 10 times more common in black and Chinese than in white SLE patients ${ }^{1}$ almost all the patients in the present study were white. Anti-SL antibody seems to show no such racial preponderance: one of our patients was Chinese, one black, two Indian, two Greek, and the remaining 21 were English-much in line with our overall patient population. The number of precipitin systems in SLE is quite limited. ${ }^{1}$ SL antibody is identical with the $\mathrm{Ki}$ system reported in Japanese patients with $\operatorname{SLE}^{20}$ and the antigens have the same molecular weight (T Mimori and RMB, unpublished data). A relation between $\mathrm{SL}$ and the $\mathrm{Su}$ system $^{21}$ also seems likely and is being explored. Further studies are required to elucidate the cellular function of SL antigen and to show how in some patients this protein becomes the target of an autoimmune response.

We thank Professor M J R Healy for expert statistical advice, Professor J R Batchelor, Dr K I Welsh, and Mr A Dodi for the tissue typing, and Miss $\mathrm{C}$ Herrmann for expert technical assistance. This work was supported in part by a grant to MBM from the Muscular Dystrophy Association and a travel grant to MBM and RMB from NATO.

\section{References}

1 Bernstein R M, Bunn C C, Hughes G R V, Francoeur A M, Mathews M B. Cellular protein and RNA antigens in autoimmune disease. Mol Biol Med 1984; 2: 105-20.

2 Notman D D, Kurata N, Tan E M. Profiles of antinuclear antibodies in systemic rheumatic diseases. Ann Intern Med 1975; 83: 464-9.

3 Harmon C. Peebles C. Tan E M. SL-a new precipitating system. Arthritis Rheum 1981; 24: S122.

4 Tan E M, Cohen A S. Fries J F, et al. The 1982 revised criteria for the classification of systemic lupus erythematosus. Arthritis Rheum 1982: 25: 1271-7.

5 Fleiss J L. Statisfical methods for rates and proportions. New York: Wiley, 1973.

6 Daniel C. Use of half-normal plots in interpreting factorial twolevel experiments. Technometrics 1959; 1: 311-41.

7 Bernstein R M. Antinuclear antibodies: clinical associations and predisposing factors. University of Cambridge, 1984. (MD thesis.)

8 Bernstein R M. Bunn C C, Hughes G R V. Identifications of antibodies to acidic antigens by counter immunoelectrophoresis. Ann Rheum Dis. 1982; 41: 554-5.

9 Bernstein R M. Steigerwald J C. Tan E M. Association of antinuclear and antinucleolar antibodies in progressive systemic sclerosis. Clin Exp Immunol 1982; 48: 43-51.

10 Wooley P M. Griffin J. Panayi G S, Batchelor J R, Welsh K I, Gibson T J. HLA-DR antigens and toxic reaction to sodium aurothiomalate and D-penicillamine in patients with rheumatoid arthritis. $N$ Engl J Med 1980; 303: 300-2.

11 Francoeur A M, Mathews M B. Interactions between RNA and the lupus antigen $\mathrm{La}$ : formation of a ribonucleoprotein complex in vitro. Proc Natl Acad Sci USA 1982: 79: 6772-6.

12 Mathews M B, Reichlin M, Hughes G R V, Bernstein R M. Anti-threonyl-tRNA synthetase: a second myositis-related autoantibody. $J$ Exp Med 1984; 160: 420-34.

13 Laemmli U K. Cleavage of structural proteins during the assembly of the head of bacteriophage T4. Nature 1970; 227: 680-5.

14 Towbin M. Stachelin T. Gordon J. Electrophoretic transfer of proteins from polyacrylamide gels to nitrocellulose sheets: procedure and some applications. Proc Natl Acad Sci USA 1979; 76: 4350-4.

15 Cleveland D W, Fischer S G, Kirschner M W, Laemmli U K. Peptide mapping by limited proteolysis in sodium dodecyl sulfate and analysis by gel electrophoresis. J Biol Chem 1977; 252: 1102-6.

16 Venables P J W, Smith P R, Maini R N. Purification and characterization of the Sjögren's syndrome $\mathrm{A}$ and $\mathrm{B}$ antigens. Clin Exp Immunol 1983; 54: 731-8.

17 Mathews M B, Bernstein R M, Franza B R, Garrels J. Identity of the 'proliferating cell nuclear antigen' and 'cyclin'. Nature 1984; 309: 374-6. 
358 Bernstein, Morgan, Bunn, Gainey, Hughes, Mathews

18 Alarcon-Segovia D. Mixed connective tissue disease: a decade of growing pains. J. Rheumatol 1981; 8: 535-40.

19 Bernstein R M. Mathews M B. Jo-1 and other myositis autoantibodies. Proceedings of the 1985 meeting of the International League against Rheumatism. Amsterdam: Elsevier, 1986.

20 Tojo T. Kaburaki J. Hayakawa M. Okamoto T. Tomii M,
Homma M. Precipitating antibody to a soluble nuclear antigen 'Ki' with specificity for systemic lupus erythematosus. Ryumachi 1981; 21 (suppl 1): 129-34.

21 Treadwell E L, Alspaugh M A, Sharp G C. Characterization of a new antigen-antibody system (Su) in patients with systemic lupus erythematosus. Arthritis Rheum 1984; 27: 1263-71. 